\title{
TEOLOGICKÁ ETIKA VYBRANÝCH RUSKÝCH PRAVOSLAVNÝCH MYSLITELU゚
}

\author{
K A R E L S L Á D E K
}

$P_{\text {i }}$ ředstavit teologickou etiku $\mathrm{v}$ perspektivě pravoslavné teologie by možná mnozí považovali za nesnadné, jelikož vycházejí z předpokladu, že se $v$ pravoslavné teologii nevyskytuje mnoho děl specificky zaměřených na morální teologii. Toto mínění je pochopitelné z jistého úhlu pohledu. $\mathrm{V}$ pravoslavné teologii totiž nedošlo $\mathrm{k}$ tak jasnému vyhranění jednotlivých teologických disciplín, jak jsou známy ze západní latinské teologie od dob středověké scholastiky. Křestanský východ zůstal v původní gnosticko-sapienciální teologické linii patristických autorů, pro kterou filosofie a teologie, dogmatika a teologická etika, mystika a liturgika tvoří jeden nedělitelný celek. ${ }^{1}$

Přesto $\mathrm{v}$ současné pravoslavné teologii můžeme vysledovat tři specifická východiska v představení morální teologie: 1. filosofické, ovlivněné kantovstvím a založené na rozumové přirozenosti člověka; 2 . kristocentrické, podtrhující důležitost života Ježíše Krista a vztah vykoupeného člověka s Kristem; 3. existenciálně-personalistické, vyzdvihující osobní zkušenost a zdůrazňující skutečnost, ve které konkrétně jednající člověk nežijící v Kristu není plně člověkem. ${ }^{2}$

Následující článek představí tři pohledy na teologickou etiku z pera tří ruských pravoslavných autorů, kteří vycházeli z těchto tří východisek, přičemž každý z nich kladl větší důraz na ten či onen aspekt v morální reflexi. Velmi zajímavé je sledovat, jak se důraz v etických východiscích měnil s historicko-politickými proměnami společnosti de-

1 Srov. KOHUT, Vojtěch. Co je spirituálni teologie? 1. vydání. Praha: Karmelitánské nakladatelství, 2007, s. 12-15.

2 Srov. HARAKAS, Stanley. Toward Transfigured Life: The Theoria of Eastern Orthodox Ethics. 1. vydání. Minneapolis: Light and Life Publishing Co., 1983, s. 13-15. 
vatenáctého a první poloviny dvacátého století. Zároveň je patrný hlavní pramen, ze kterého všichni tři čerpali, a tím je osobní vztah ke Kristu, a hlavní cíl: zpřítomnit etické principy Božiho království.

Z textu bude rovněž zřejmé, že teologická etika má nadčasový „prorocký úkol“, který může mít v různých dobách různé podoby. Jednotlivé kapitoly sledují stěžejní díla o etice těchto autorů: Vladimír Solovjov (1853-1900), Nikolaj Losskij (1870-1965) a Pavel Evdokimov (1901-1970). ${ }^{3}$

\section{Solovjovovo etické ospravedlnění dobra}

Vladimír Solovjov si již v mládí vytyčil svůj badatelský cíl, a to zpracovat během života působení ontologických principů pravdy, dobra a krá$s y$ v kosmickém a historickém procesu. Atribut dobra neboli etické principy zpracoval v devadesátých letech 19. století v monumentálním díle Ospravedlnèní dobra (etická filosofie), ${ }^{4}$ ve kterém představil aspekty etiky v celé širri své syntézy soudobé vědy, filosofických směrů a teologického myšlení. Solovjov hledá etickou bázi pro brzkou realizaci Božiho království. Jeho hlas lze vzhledem k atmosféře doby, ve které žil, právem nazvat prorockým. Optimismus období Alexandra II. a nadšení pro změny po úspěšném atentátu na cara nenávratně vyprchávaly. Vladimír Solovjov se snažil udržet pozitivní atmosféru předchozích let, ale zároveň společnost navést na jinou realitu než na utopistické zítřky šírící se marxistické ideologie.

Kniha je rozdělena do celkem tří rozsáhlých částí (a devatenácti kapitol): Dobro v lidské prírozenosti, Dobro od Boha a Dobro vznikajici prostrednictvím lidských déjin. V první části zvané Dobro v lidské prírozenos$t i$ Solovjov analyzuje rozdíl mezi člověkem a živočichy z pohledu etiky. Souhlasí s Darwinem, že nejvýraznější rozdíl je v př́tomnosti mravního citu. Dělícím kritériem je zde svédomí, tedy poznání a zhodnocení dobra a zla. Solovjov podrobuje empiricko-psychologickému zkoumání tři prvotní základy mravnosti: stud, soucit a posvátnou úctu pred vyšším. Nakonec dospívá k závěru, že je to stud, který člověku říká, že „toto je ne-

3 Článek je výstupem z grantu Akademie věd České republiky IAA908280902 s názvem „Život a vliv Nikolaje Losského v akademickém světě prvorepublikového Československa“.

4 Dílo vyšlo v ruském originále v rámci sebraných spisů Vladimíra Solovjova: LOSEV, Alexej (ed.). Соловьев В. С.: Сочинения в 2 m. 2 sv. Moskva: Mysl, 1988. Český překlad vydalo nakladatelství Refugium: SOLOVJOV, Vladimír. Ospravedlněni dobra. 1. vydání, Velehrad: Refugium, 2002. V této studii ovšem budeme vycházet z vlastních překladů z ruského originálu. 
dovolené a nepřijatelné, provinil ses zlem, hříchem a zločinem“.5 Mravní pravidla vycházející ze studu, soucitu a altruismu, tj. spravedlnost a milosrdenství, nelze oddělit od náboženského principu posvátné úcty. Své úvahy ukončil v meditaci o provázanosti teologálních ctností (víry, nadèje a lásky), které negativní asketický postoj ke světu a tělu posouvají do nové duchovní roviny. Dvojí novozákonní přikázání lásky k Bohu a bližnímu je pro Solovjova hlavním principem pro poznání principů pozitivního mravního jednání. ${ }^{6}$

Od člověka pak Solovjov obrací svůj pohled k Bohu. V druhé části knihy s názvem Dobro od Boha opět začíná analyzovat stud a soucit a spekulativní cestou dospívá k trojímu vztahu vzhledem k náboženskému prožit$k u$.

„A tak se úplný náboženský vztah logicky skládá ze tří mravních kategorií: 1. nedokonalosti (v nás), 2. dokonalosti (v Bohu) a 3. zdokonalování (čili slad’ování prvního s druhým), což je naším životním úkolem. “7

Centrální událostí pro poznání dokonalosti v Bohu je událost vtělení Bohočlověka Ježíše Krista, přičemž ve spojení s ním se člověk očištuje od nedokonalostí a přimykáním k jeho boholidství zdokonaluje svoji př̀rozenost procesem zbožšténí. Život Bohočlověka Ježíše Krista analyzoval Solovjov v kontextech univerzálního kosmicko-historického procesu, ve kterém Kristus překonal pokušení zlého kosmického principu a odhalil světu svoji boholidskou podstatu. ${ }^{8}$

V třetí nejobsáhlejší části Dobro vznikající prostřednictvím lidských dèjin analyzuje historický proces. Zastavme se u otázky trestněprávní, ve které Solovjov namnoze překročil svou dobu a svým křestanským humanismem ukázal cestu ke smyslu věznění jakožto období vlastní nápravy. $\mathrm{V}$ době, kdy psal tyto řádky, bylo běžné užívat při výsleších mučení, psychicky vydírat vězně fiktivními popravami (nejznámějším př́ikladem byla výstražná poprava mladého Fjodora Dostojevského), ${ }^{9}$ deportace na Sibiř a život $\mathrm{v}$ ponižujících podmínkách, každodenní popravy. Solovjov proti této všeobecně rozšířené praxi doporučuje křestanské altruistické přikázání lásky. Trestněprávní nauka, jak byla ve společnosti realizována, je podle jeho názoru jen transformace starozákonní logiky principu krevní msty.

LOSEV, Alexej (ed.). Соловьев В. С.: Сочинения в 2 m. Sv. 1, s. 133.

Srov. LOSEV, Alexej (ed.). Соловьев В. С.: Сочинения в 2 m. Sv. 1, s. 193.

LOSEV, Alexej (ed.). Соловьев В. С.: Сочинения в 2 m. Sv. 1, s. 253.

Srov. LOSEV, Alexej (ed.). Соловьев В. С.: Сочинения в 2 m. Sv. 1, s. 268.

9 Srov. MOČUL'SKIJ, Konstantin. Гоголь, Соловьев, Достоевский. 1. vydání. Moskva:

Respublika, s. 282-293. 
„Trestněprávní doktrína odplaty má takto historický základ v tom smyslu, že tresty, které jsou ještě dnes uskutečňovány, představují historickou transformaci prvobytného principu krevní msty. Dříve se za ublížení mstil užší společenský svaz zvaný rod, potom se začal mstít rozsáhlejší a složitější, nazývaný stát.“10

Historický proces podle Solovjova směřuje k odstranění principu rovnoměrné odplaty - popravy za vraždu. Vystupuje proti trestu smrti, mučení a krutým trestům jako prostředku zastrašování. „Trest jakožto odstrašující odplata (jeho typickou formou je trest smrti) nemůže z mravního hlediska být obhájen, protože ve zločinci popírá člověka, zbavuje ho práva na existenci a na mravní obrodu, která patří každému.“11

Za trestněprávní reflexi Solovjov záměrně zařadil otázku etiky v ekonomii, jelikož také zasahuje do sféry zločinnosti a národnostní nenávisti, jak ji vysvětluje $\mathrm{v}$ šestnácté kapitole. Ekonomika opustila směřování k dobru, proto Solovjov vyzývá k návratu ke všeobecné solidaritě s chudými. Kritizuje čistě ekonomické chápání života, a to jak u zastánců kapitalistického trhu, tak u socialistů. „Samotný fakt ekonomické bídy je důkazem toho, že ekonomické vztahy nejsou spojeny, jak by bylo tomu třeba, s principem dobra. Nejsou organizovány mravně. Celá domněle vědecká škola ekonomických anarchistů-konzervativců přímo popírala a ještě popírá, ač bez dřívějších postojů, všechny etické principy a veškerou organizaci v oblasti hospodářských vztahů, a její vláda se tak nemalou měrou podílí na vzniku revolučního anarchismu. “12

Solovjov svůj postoj vůči nekontrolovatelným a samohybně plynoucím materialistickým mechanismům zákonů trhu vyjádřil slovy: „Stejně jako volná hra chemických procesů může probíhat jedině v mrtvole, ale v živém těle jsou tyto procesy spojené a určené organickými cíli, tak je volná hra ekonomických faktorů a zákonů možná jedině v mrtvé a rozkládající se společnosti, ale v živé společnosti, která má budoucnost, jsou hospodářské elementy spojené a určované mravními cíli.“13

Hlavní problém kapitalismu i socialismu spatřuje Solovjov v čirém materialismu, jenž se promítá do chybně pojaté antropologie, ve které jsou člověk a společnost redukováni na ekonomické vztahy. ${ }^{14}$ Jako kritérium pro hospodářství budoucí společnosti staví trojjediný mravní princip

10 LOSEV, Alexej (ed.). Соловьев В. С.: Сочинения в 2 m. Sv. 1, s. 386.

11 LOSEV, Alexej (ed.). Соловьев B. С.: Сочинения в 2 m. Sv. 1, s. 402.

12 LOSEV, Alexej (ed.). Соловьев В. С.: Сочинения в 2 m. Sv. 1, s. 407.

13 LOSEV, Alexej (ed.). Соловьев B. С.: Сочинения в 2 m. Sv. 1, s. 408.

14 LOSEV, Alexej (ed.). Соловьев В. С.: Сочинения в 2 m. Sv. 1, s. 416. 
vztahu k Bohu, lidem a př́rodě. Vyzývá ke zlepšování sociálně ekonomických vztahů, které mají vést k solidaritě a sbližování lidí, tj. v konečném důsledku eliminovat působení zla ve společnosti.

Poslední argument, který bude v této části analyzován, je Solovjovův postoj ke smyslu války. Solovjov na jednu stranu jasně postuluje, že „válka je zlo“, ${ }^{15}$ na druhou stranu vidí válku v historickém vývoji také jako pozitivum, avšak „ne v tom smyslu, že by sama o sobě byla normální, ale jen v tom, že bývá za daných podmínek skutečně nezbytná“. ${ }^{16}$

Solovjov analyzuje války $\mathrm{v}$ celé lidské historii (např. trójskou válku, války Alexandra Makedonského či ideu Pax Romana v dobyvačných aktivitách Římanů) až do příchodu křestanství, jež posléze též bojovalo mečem za duchovní sjednocení lidstva či za jeho obranu (boje Konstantinovy či španělsko-islámský konflikt). Nechce vyloučit válku jako prostředek obrany.

Ve svém posledním díle nazvaném Tři rozhovory se válkou taktéž vážně zabýval. Jeho postoj nebyl propagací války, spíše kritizuje pozici pasivity před šírícím se zlým principem. V závěru života také změnil svůj předchozí optimistický náhled na směřování lidstva, ve kterém doufal v realizaci dobra pokojným historickým vývojem. Již nevěřil, že na zemi lze vymýtit válku před závěrečnou apokalypsou, jelikož zde stále působí „démonické síly“. Přesto jsou pro něj cílem dobra mír a harmonie mezi lidmi, které jsou ale založeny na pokoji Kristově. ${ }^{17}$ Solovjovovi bylo zřejmé, jak je svět vzdálen od Božiho království, ale přesto na konci kapitoly Smysl války v Ospravedlnèni dobra (etickáfilosofie) představil svůj ideální sen o lidském uspořádání, ve kterém již válka nebude mít místo. „Válka byla přímým prostředkem pro vnější a vedlejším prostředkem pro vnitřní sjednocení lidstva. Rozum nám zakazuje odvrhovat tento prostředek, dokud je ho potřeba, ale svědomí nás zavazuje snažit se, aby přestal být nutným a aby přirozená organizace lidstva rozděleného na nepřátelské části skutečně přešla do jeho mravní čili duchovní organizace.“18

\section{Losského etika v boji za Boží království}

Ruský intuitivista Nikolaj Losskij se nesmazatelně zapsal do českého prvorepublikového filosofického bádání a přispěl zde k rozvoji části české filosofické obce, která své poznání opřela o metafyzické předpoklady. Zá-

15 LOSEV, Alexej (ed.). Соловьев В. С.: Сочинения в 2 m. Sv. 1, s. 464.

16 LOSEV, Alexej (ed.). Соловьев B. С.: Сочинения в $2 \mathrm{~m}$. Sv. 1, s. 464.

17 SOLOVJEV, Vladimír. Trí rozhovory. 1. vydání. Praha: Zvon, 1997, s. 26-27.

18 LOSEV, Alexej (ed.). Соловьев B. С.: Сочинения в 2 m. Sv. 1, s. 484. 
kladním pramenem pro poznání Losského náhledu na etiku je bezesporu jeho kniha Podmínky dokonalého dobra. Nakladatelství Matice slovenské ji vydalo roku 1944 ve slovenském překladu, který zajistil Losského slovenský obdivovatel Josev Dieška. ${ }^{19} \mathrm{~V}$ úvodu knihy Losskij píše: „Etika je věda o mravním dobru a zlu a jeho uskutečňování v činnosti člověka. Etika zkoumá konečný cíl života člověka a jeho činnosti, nakolik ho vede k dosažení tohoto cíle nebo k odklonu od něho.“20

V prvních kapitolách vychází ze základních principů etiky a obhajuje potřebu transcendentního rozměru člověka. Kriticky se vypořádává s hedonismem, eudaimonismem, biologismem a naturalistickým evolucionismem v etice. Zejména rozebírá agnosticismus Spencerova naturalistického evolucionismu, který své teze rozvíjel ještě před Darwinem. Podle Spencera je altruismus a nezištné chování v konečném důsledku egoistické, nevybočuje z kritéria hledání vlastní rozkoše, takže altruismus a egoismus vlastně splývají, což je pro Losského nepřijatelná teorie zaměňující prostředek (rozkoš) s cílem, kterým je v Losského pojetí dokonalá a absolutní krása, dobro a pravda. Kritika Losského je jistě na místě, jelikož tyto teorie mohou vést k banalizaci, maskování a někdy dokonce ospravedlnění působení zla skrze člověka, skrze institucializovanou zlovolnou ideologii.

Cíl chování člověka vidí Losskij v „nadbiologickém principu“. Altruistické chování a vzájemná pomoc není podle Losského pohnutkou egoistickou, ale citu lásky, která se dokáže vcítit do utrpení druhého a chce mu pomoci z jeho tíživé situace. Podle Losského je vize světa organická a v celistvosti jednotná, kde každá část nežije jen pro sebe, ale pro druhého. V tomto konceptu navázal na paradigma slavjanofilského dědictví. Ve svém komplexním světonázoru postavil proti sobě odpadlé bytí psychomateriálni ríše a Boži království, kde jsou všechna těla vzájemně proniknuta, tedy nemateriální, spojená dokonalou láskou v kosmickém těle, které objímá celý svět. ${ }^{21}$

V souladu se Solovjovem považuje Losskij fenomén lidského svědomí za již vyšší řídící faktor přesahující vlastnosti materie a indikující transcendentní přícinu. V Podmínkách dokonalého dobra píše: „Základ svě-

19 Srov. LOSSKIJ, Nikolaj. Воспоминания. 1. vydání. München: Wilhelm Fink Verlag, 1968, s. 284.

20 LOSSKIJ, Nikolaj. Условия абсолютного добра. [strojopis; bez uvedení místa a roku], s. 1. V textu budou užity vlastní překlady z ruštiny z tohoto nedávno nalezeného (zřejmě původního) svázaného strojopisu nacházejícího se ve Slovanské knihovně NK Praha pod signaturou Rb 3765.

21 Srov. LOSSKIJ, Nikolaj. Условия абсолютного добра, s. 31. 
domí, individuální a normativní idea, je principem natolik hlubokým a vzdáleným od chudoby pozemského bytí, že jeho dokonalé poznání je nemožné v pozemských podmínkách; proto se výroky svědomí ozývají $\mathrm{z}$ temných útrob ducha a mohou být různě zdůvodněné jen v nejjednodušších př́ípadech, kdy je řeč o splnění požadavků zákonní etiky, tedy té, která je vyjádřena ve všeobecných pravidlech konání."22

Losskij se rovněž neopomněl zaměřit na pedagogické otázky výchovy, veřejných a právních trestů. Kromě př́mého imanentního trestu (výčitky svédomi) Losskij uznává i odvozený imanentní trest, který má smysl v izolaci individuálního egoismu škodícího společnosti, aby duše potrestaného mohla odepřením svobody a izolací od společnosti najít čas k rozpoznání viny a činit pokání. Ve chvíli konání trestného činu a i těsně po něm totiž ještě nenahlédla zlo, které páchá. Ohledně legislativy Losskij požaduje individualizaci trestů, tedy odvodit výši a způsob trestu podle mnoha faktorů - bere $\mathrm{v}$ potaz individualitu zločince, důvody a okolnosti spáchání činu atd. Na rozdíl od Solovjova, který z křestanských pozic radikálně vystupoval proti trestu smrti a kvůli požadavku milosti pro carovrahy skončila jeho slibná akademická dráha, Losskij trest smrti neodsuzuje zcela, ale taktéž ho považuje za nedokonalý prostředek boje proti zlu v prrípadě nejkrutějších a nejnehumánnějších zločinů. ${ }^{23}$

V závěru knihy Podmínky dokonalého dobra Losskij reflektuje i otázky sociálního pokroku, hospodářského zřízení a vzdělanosti společnosti. Lidské snažení při hledání optimálního ekonomického systému by mělo být zaměřeno na solidaritu se sociálně slabšími a mělo by hledat takový model, který by snížil bídu mezi sociálními vrstvami. Losskij podporuje silný stát, který je štědrý ke všem, dbá na ekonomický i duchovní rozvoj společnosti, podporuje plošný rozvoj zdravotnictví, všeobecné vzdělávání obyvatelstva a zajištuje kolektivní bezpečnost. Kritizuje ale ideu násilného socialismu, přičemž proměnu hospodářského systému vidí jen za předpokladu svobodného rozhodnutí lidí směřovat k dobru. ${ }^{24}$ Mravní pokrok i úpadek společnosti závisí na svobodné volbě činitelů, kteří odloučeni od Boha usilují o své zbožštění nebo v opačném případě propadají do regresu v egoistické evoluci. ${ }^{25}$

$\mathrm{V}$ roce 1934 vydal Losskij v češtině knihu Industralism, komunism a ztráta osobnosti. Ve velmi zdařilém pojednání vyslovuje „prorockým

\footnotetext{
LOSSKIJ, Nikolaj. Условия абсолютного добра, s. 61.

23 Srov. LOSSKIJ, Nikolaj. Условия абсолютного добра, s. 98-103.

24 Srov. LOSSKIJ, Nikolaj. Условия абсолютного добра, s. 163-167.

25 Srov. LOSSKIJ, Nikolaj. Условия абсолютного добра, s. 168-170.
} 
duchem“ obavu z vývoje společnosti, která ani dnes neztratila nic na své aktuálnosti. U soudobé kultury tuší riziko odosobnění a odumření duchovního života. Kriticky hledí nejen na rodné Rusko (Sovětský svaz), ale též na USA a Německo. Vyzdvihování kolektivu na úkor individua vede ke ztrátě přátelství člověka s člověkem, jelikož „v zemi, kde hodnota kolektiva je prohlášena za absolutní, vyzvědačství a udavačství je velebeno jako ctnost“. ${ }^{26}$ Vývoj čistě naturalistického světového názoru, který vylučuje nadbiologické funkce člověka, by v konečné fázi skončil snahou vyhubit slabé či znetvořené děti, lidi nevyléčitelně nemocné či choromyslné, staré. Proti těmto tendencím postavil Losskij křestanské náboženství, které hájí práva člověka a rodiny založená na absolutní hodnotě osobnosti. ${ }^{27}$

\section{Neopatristická teologická etika Pavla Evdokimova}

Ještě citlivěji vnímala působení zla v lidských dějinách mladší generace ruských emigrantů. Ve své dizertaci z filosofie, kterou Pavel Evdokimov pojmenoval Dostojevskij a problém zla, se - jak již název napovídá - otázce zla pečlivě věnuje. Apokalyptický ráz dějin první poloviny dvacátého století si žádal hlubší teologické pochopení, což se odrazilo v nauce mnohých začínajících teologů. Ve své dizertaci rozebírá Dostojevským rozpracované románové postavy $\mathrm{v}$ kontextu teologické antropologie, etiky a spirituální teologie, respektive se v první části zaměřuje na pochopení osudu a smyslu života člověka, jeho duchovního růstu či regresu. $V$ druhé části rozebírá původ, principy a přirozenost zla. $V$ třetí části pak vysvětluje původ zla v historickém procesu, a to na prríkladu Dostojevského úryvku z Bratrů Karamazových s názvem Legenda o Velkém Inkvizitorovi. Dále rozebírá Babylonskou věž humanismu s hledáním nadčlověka, liberalismem a nihilismem, s eschatologickou tragikou zla.

Jaké jsou tedy základní myšlenky Pavla Evdokimova? Člověk po pádu nemůže nahlížet realitu ráje, proto ve svém srdci nejprve poznává působení zla, nad kterým může vyhrát svobodným odmítnutím. V opačném př́padě zlému principu podlehne a vytvoří sobě i druhým peklo - ř́iši $S a$ tana. Stejně jako je zřejmé, že Solovjov v poměrně optimistické a relativně pokojné době začal svou etickou studii analýzou působení dobra v lid-

26 LOSSKIJ, Nikolaj. Industrialism, komunism a ztráta osobnosti. 1. vydání. Praha: Nakladatelství L. Souček, 1934, s. 10.

27 LOSSKIJ, Nikolaj. Industrialism, komunism a ztráta osobnosti, s. 11. 
ské přirozenosti, Evdokimovova prvotní reflexe vychází naopak z analýzy působení zla, což je v kontextu hrůz druhé světové války rovněž pochopitelné. Na mnohých postavách Dostojevského Evdokimov dokumentuje tragickou skutečnost svobodného odmítnutí duchovní dimenze života, po kterém následuje regres směrem k vášním, absolutnímu nezájmu a nenávisti k životu. K obnově člověka a jeho původního nevinného Božího obrazu dochází vnitřní proměnou v setkání s Kristem za aktivního působení Ducha svatého.

„Pojetí Krista jako ideál člověka není nic jiného,“ píše Evdokimov, „než potvrzení konkrétní skutečnosti člověka, který žije ,en Christó6. To nemá nic společného s moralistickou koncepcí. Nejedná se o imitování, ale jde o vtělení obrazu Krista, theósis, po které člověk musí zemřít a znovu se narodit.“28

Z tohoto konstatování je zřejmé, že Evdokimovova teologická antropologie je ryze kristocentrická. $\mathrm{Z}$ dále uvedeného bude též patrné, že je zároveň pneumatocentrická. Jak ve své dizertaci rozvádí, společnost je v Dostojevského románech vytvářena člověkem, který do ní projektuje hnutí svého nitra, proto může být bud' rájem, nebo peklem - záleží na tom, zda se člověk otevře Kristu, nebo Satanu. Tolik základní teze Evdokimovovy prvotiny, ve které se vyrovnal s působením zlého a zároveň si připravil půdu pro další teologické reflexe, ve kterých se již více zaměřil na realitu „nového života“ v Kristu a z něho vyplývajících etických východisek chování.

Slibnou akademickou dráhu započal Pavel Evdokimov na Bohosloveckém institutu sv. Sergeje, který v Pařiži založili ruští emigranti roku 1925. Zde vyučoval dějiny západního křestanství a morální teologii. Jeho teologická etika vychází z předpokladů teologie „proměněného člověka v Kristu“. Přímo se opírá o zjevené dogma o boholidství Ježíše Krista, se kterým se procesem zbožšténi a skrze božské energie sjednocuje lidská osoba. Člověk je nahlížen jako Bohem stvořený „projekt“ pro participaci na Jeho trojičním životě. Teologická etika se opírá o poznání a uchopení reality „nového stvořeni““ obnoveného Duchem svatým skrze svátosti Církve. Etika proměněného života $\mathrm{v}$ Kristu vychází z tajemství křtu, který otevírá cestu ke svatosti.

„Naše tvrzení následuje svatého Pavla,“ píše Evdokimov a dodává: „a má jen jeden cíl: vysvětlit ontologický status každého věřícího ,trans-esenciálním‘ odlišením mezi starým člověkem, přirozeným, a ,novým

28 EVDOKIMOV, Pavel. Dostojevskij e il problema del male. Roma: Città Roma, 1995, s. 105. 
stvořením‘. Ale zde každá fenomenologická analýza přechází k ,trans-fenomenologii‘, jelikož dochází $\mathrm{k}$ tomu, co je za bezprostředně vyjevovaným a co je tajemstvím svatosti.“ ${ }^{29}$

Fundamentální etika je zde plně zakotvena v „teologii lidské osoby“. V otázce morálních zásad nejde tolik o vnější výchovu lidského vědomí, ale o zkušenost jeho osvícení a očištění Pravdou, která osvobozuje. V díle Ortodoxie se Evdokimov ohrazuje proti jakémukoliv moralismu v křestanství a poukazuje na specifikum morální teologie, jež vychází z teorie o ontologickém zbožštění, ke kterému dochází v Církvi - místě metamorfózy života v boholidskou přirozenost Krista. ${ }^{30}$ Asketické obrácení - metanoia - očištuje padlé vášně, které zpřetrhaly vazby s Bohem. Nepřetržitá modlitba obnaží lidské ego pro působení božských energií, které naplní člověka tichostí a pokojem - hésychii. ${ }^{31} \mathrm{Z}$ této proměněné reality je podle Evdokimova potřeba vycházet v morální teologii. „Zde je přirozený rozdíl mezi asketismem a moralismem. Moralismus určuje etické chování tím, že ho podřizuje morálním imperativům. Ale kompozice založená na přirozených silách je křehká a v jejím zdání se velmi lehce schová farizejská „pýcha pokorných', zatímco ,ctnost' podle askeze je lidský dynamismus vystavený Boží přítomnosti. “32

Obdobně jako Solovjov a Losskij se také Pavel Evdokimov snažil číst „znamení časů“. Dotkl se tedy i otázek sociální etiky. V roce 1967 reagoval na encykliku papeže Pavla VI. Populorum progressio, reflektující problém ekonomického a sociálního vývoje. Církev by podle Evdokimova měla být morálním svědomím lidstva. $\mathrm{V}$ tom podle jeho mínění papežské encykliky daleko předstihly pravoslavnou církev. ${ }^{33}$ Upřednostňuje církev „chudou a sloužící“, která se ve své kenozi solidarizuje $\mathrm{s}$ utiskovanými a trpícími v očekávání eschatologické spravedlnosti. Řešení problémů světa a překonání kapitalismu vidí v jediné možné revoluci - v evangeliu.

„A tak problém překonání kapitalismu a technokracie, problémy třetího světa, války a hladu, ožehavé problémy světové úrovně, jsou aktuální pro všechny Církve a křestanské svědomí. Ovšem jediná účinná revoluce může přijít jen $\mathrm{z}$ evangelia, protože zde sám Bůh přichází $\mathrm{k}$ člověku, aby

29 EVDOKIMOV, Pavel. Il mistero della persona umana. In ID. La vita trasfigurata in Cristo. 1. vydání. Roma: Lipa 2001, s. 201.

30 Srov. EVDOKIMOV, Pavel. L’Ortodossia. 3. vydání. Bologna: EDB, 1981, s. 132.

31 Srov. EVDOKIMOV, Pavel. L'Ortodossia, s. 149-150.

32 EVDOKIMOV, Pavel. L'Ortodossia, s. 142.

33 Srov. EVDOKIMOV, Pavel. La Chiesa e la società. In EVDOKIMOV, Pavel. La vita trasfigurata in Cristo, s. 235. 
ho získal pro Království a ustanovil spravedlnost. Podle Apokalypsy Kristus je ten, který ,je, byl a přijde‘ - a ,Ten, který přijde‘ již svědčí, že my přijdeme do nového historického eónu, který bude úplně jiný. “34

Před mlčením „dobrých“ vyzdvihuje Evdokimov nenásilné násili Mahátma Gándhího a Martina Luthera Kinga, které pramení z vnitřního obrácení a uchopení tajemství trpícího Boha. Po vzoru patristických otců Evdokimov vyzývá k duchovní proměně lidstva a k evangelijní metanoie, ze které pramení povinnost spravedlnosti a almužny před třetím světem. Církve má pod „eschatologickým tlakem“ Ducha svatého sjednocovat věřící všech náboženství a přinášet mír. Stát potom podle Evdokimovovy intuice nemá za úkol přinášet totalitní pozemský ráj, realizovat „pozemské království“, ale pouze zabraňovat tomu, aby se země nestala peklem.

\section{Závèr}

Předložený článek představil etické reflexe tři ruských pravoslavných myslitelů, kteří od sebe byli generačně vzdáleni, avšak každý z nich svým způsobem „prorocky“ reflektoval etické otázky své doby. Odlišnosti těchto autorů v přístupu k etice pramení do jisté míry z odlišných výzev, které přinášely dějiny, v nichž žili a tvořili. Vladimír Solovjov představuje generaci „stř́brného věku“ ruského myšlení, která se snažila o novou syntézu mezi vědou, filosofií a teologií. Solovjov žil v poměrně klidné a optimistické době devatenáctého století vkládající velkou důvěru v rozum člověka. $\mathrm{Z}$ této pozitivní atmosféry záměrně vychází a chce připravit společnost na přijetí nikoliv pozemského blahobytu, ale na rozpoznání duchovních hodnot Božiho království. V představování etiky začal od analýzy lidské přirozenosti, což bylo v době ovlivněné Kantovou filosofií běžné. Ke konci svého života byl více rezignovaný a své dílo zasvětil apokalyptice - eschatologickému boji dobra se zlem.

Nikolaj Losskij, ovlivněn Solovjovem, pokračuje v ideové linii hledající novou syntézu, ovšem je ovlivněn radikálními geopolitickými změnami první poloviny dvacátého století. Jeho etika v prvé řadě předkládá, co i na teoreticko-praktické rovině umožnilo rozvoj těchto „temných sil“. A opět nezapomněl „prorocky apelovat“ na způsob, jak se navrátit k ideálu Božiho království.

Nejmladší ze zde studovaných ruských autorů, Pavel Evdokimov, již převážnou část života žil, studoval a vyučoval v pařížském exilu. Repre-

34 EVDOKIMOV, Pavel. La Chiesa e la società, s. 235. 
zentuje novou generaci ruských emigrantů, kteří v kulturně odlišném prostředí hledají zakotvení své pravoslavné identity $\mathrm{v}$ návratu k patristice. Neusiluje tolik jako předchozí generace o novou syntézu dosavadního poznání, ale o aktualizaci a zpř́tomnění patristického myšlení. Východiskem pro etiku je pro něj „novost života“ v Kristu, proměna v Duchu svatém a život z liturgicko-svátostného poslání Církve.

Karel Sládek (1973), Katedra teologické etiky a spirituální teologie KTF UK

\section{ABSTRACT \\ KAREL SLÁDEK \\ The Theological Ethics of Selected Russian Orthodox Thinkers}

This study introduced ethical reflection of the three Russian Orthodox thinkers who apocalyptically reflected ethical questions of their era, in spite of the generation gap between them. Vladimir Solovjov, with his determination of the defense of the good, wanted to prepare the society of the $19^{\text {th }}$ century not for the reception of an earthly prosperity, but for the recognition of the divine value of the Divine Kingdom. In the ethics Nikolaj Losskij is the first to discover the theoretical-practical facilitation of the development of the Dark Power in the first half of the $20^{\text {th }}$ century. He also didn't forget to invoke divine return to the ideal of the Divine Kingdom. Pavel Evdokimov, the youngest of the Russian writers under investigation, represented the new generation of the Russian emigrés, who - in the culture of the different world - were looking for establishing his orthodox identity in the return to patrology. The starting point for his ethics is a new way of life in Christ, the metamorphosis in the Holy Ghost and the life of the liturgical-sacramental mission in the Church.

Key words

Orthodox ethics, Russian thinkers, good, Divine Kingdom and the life devoted to the Christ 